\title{
UMA NOVA FORMA DE COFFEA (1)
}

C. A. KRUG, engenheiro agrônomo, Diretor; J. E. T. MENDEs, engenheiro agrônomo, Seç̧ão de Café; A. Carvalho, engenheiro agrônomo, Seç̧ão de Genética e A. J. T. Mendes, engenheiro agrônomo, Seç̧ão de Citologia, Instituto Agronômico de Campinas

\section{1-INTRODUÇÃO}

Reunir à produtividade do cafeeiro o bom aspecto do produto e a boa qualidade da bcbida, tem sido a principal preocupação dos investigadores que, no Oriente, trabalham no melhoramento das espécies Coffea canephora Picrre ex Frœhner, Coffea congensis Frœhner, Coffea Dewevrei De Wild. et Th. Durand, e Coffea liberica Hiern. Para os que trabalham com a espécie Coffea arabica L., o problema da "boa bebida" carece de importância especial, sabido que tôdas as suas variedades econômicas a produzem da mais fina qualidade, desde que o produto scja colhido e preparado com os necessários cuidados. Na grande maioria dos trabalhos de seleção do cafeeiro, em execução no Instituto $\Lambda$ gronômico, o problema da qualidade tem sido simples, pois que as plantas em seleção pertencem tôdas à cspécie C. arabica.

Um dos principais objetivos que se tem em vista nesse plano de seleção do cafceiro (4) consiste na obtenção de formas rústicas, capazes de se desenvolverem bem e produzirem elevadas colheitas, mesmo em terras já cansadas, anteriormente cultivadas com o próprio cafeeiro. A variedade maragogipe (Coffea arabica L. var. maragogipe Hort. ex Frœhner) é a que maior rusticidade apresenta dentre os tipos econômicos desta espécie; a sua produtividade, entretanto, ainda deixa a descjar, salvo a de algumas progênies procedentes de São José do Rio Pardo, ainda em estudos. Assim, para atingir o fim em vista, resta outra alternativa, que consiste em se estudarem outras espécies de Coffea.

Desde o início dos trabalhos de melhoramento, verificou-se que uma rusticidade $\mathrm{em}$ grau bastante elevado é encontrada no cafeeiro excelsa (Coffea Deweurei De Wild. et Th. Durand var. excelsa Chev.) (1). Esta espécie, entretanto, produz um café considerado de má qualidade, quanto à bebida. Sua produção, porém, é muito elevada, e o vigor vegetativo extraordinário. Aliar, portanto, as boas qualidades do excelsa, à excelência da bebida do arábica, seria uma solução para as regiões cafeeiras de terras cansadas. Sérias dificuldades, entretanto, são encontradas na obtenção dessa forma ideal. As duas espécies, genc̀ticamente bem diferentes, não podem ser cruzadas com facilidade e, mesmo que se cruzassem, as plantas híbridas resultantes não seriam do tipo almejado. A análise citológica revelou, para o excelsa, um número somático de 22 cromosômios, e 44, para o arábica (2). Dêste modo, o cafeeiro híbrido, triplóide, será estéril ou parcialmente estéril, pelas

(1) Trabalho apresentado na Primeira Reunião Anual da Sociedale 13rasileiria para o Progresso da Ciencia, retilizada em Campinas, São Paulo, de 11 a 15 de outubro de 1949. 
anomalias que serão verificadas durante a formação dos gâmetas. Apenas a subsequente duplicação artificial do número de cromosômios, talvez restabelecesse a fertilidade normal. Outro caminho a seguir, na obtenção do referido tipo de cafeeiro, seria, primeiramente, obter uma forma tetraplóide do excelsa e cruzá-la, em seguida, com o arábica. A solução teórica é relativamente fácil ; difícil, porém, é prever o tempo que seria necessário para se conseguir tal desiderato, não se podendo ainda assegurar se o novo tipo, assim sintetizado, de fato apresentaria os caraterísticos desejados.

Às vêzes, entretanto, a natureza vem em auxílio do investigador, oferecendo, aos seus estudos, material de especial importância para a consecução dos seus fins. Assim é que em 1935 foi encontrado, numa lavoura comercial, um cafeeiro de excepcionais qualidades, o qual, apesar de não constituir ainda a forma ideal desejada, representa matéria prima de grande valor para os trabalhos em questão. Este cafeeiro, com caraterísticos gerais de excelsa, constitui objeto da presente publicaçâo.

\section{2-HISTÓRICO}

Preocupando-se em examinar os cafeeiros com vigor e produtividade excepcionais, encontrados nas lavouras de café, sempre que se recebem notícias da existência de um dêsses indivíduos, tem-se procurado estudá-lo com o devido cuidado. Assim, por informações prestadas, em 1935, pelo sr. João de Oliveira, funcionário do Instituto Biológico de São Paulo, soube-se da existência de um cafeeiro, na fazenda Itaporã, em Terra Roxa, município de Viradouro, de propriedade do sr. Guilherme Moura. Sobressaía aos demais, não só pelo elevado porte, como pela extrema rusticidade e grande produção. Segundo informações obtidas in loco, a planta fôra encontrada em um viveiro de café Bourbon - Coffea arabica L. var. bourbon (B. Rodr.) Choussy - desconhecendo-se, porém, a procedência das sementes aí plantadas. O vigor desta planta, desde logo chamara a atenção da pessoa que a transplantou para o local definitivo, à beira de um carreador de um talhão de café Bourbon. Ela cresceu ràpidamente e, como produzisse boas colheitas, o proprietário resolveu plantar alguns de seus descendentes próximo à sede da fazenda. Esta descendência, porém, se revelou extremamente desuniforme.

A planta original, na Secção de Genética, recebeu o número "387", sendo designada por êste número no presente trabalho. Vários outros cafeeiros ainda foram marcados na fazenda Itaporã, entre os descendentes do “387”, que são os de números 388 a 396 (5).

Além de pequena quantidade de frutos, foram também trazidas para Campinas estacas para enxertia do cafeeiro " 387 " e de alguns dos seus: descendentes. Os enxertos foram posteriormente plantados na coleção da Estação Experimental Central de Campinas, enquanto parte das sementes foi plantada e outra enviada a Santos, a fim de ser feita uma prova de xícara.

Em virtude da natureza dos caracteres vegetativos, como tipo de fốlha, altura, etc., o cafeeiro " 387 " foi, de início, suposto pertencer à espécie $C$. liberica. Pelo fato de ser muito produtivo e de se achar rodeado apenas por 
plantas bourbon da espécie $C$. arabica, foi considerado como constituindo uma variação autofértil dessa espécie. Mais tarde verificou-se que o " 387 " é pràticamente auto-estéril, que êle mais se aproxima da espécie C. Dewevrei e que a sua origem muito provàvelmente se deve a uma hibridação interespecífica natural entre essa e a espécie $C$. arabica.

Tratando-se de material de grande valor para a solução do problema da síntese de um novo cafeeiro para as zonas de café de terras já anteriormente cultivadas, organizou-se, na Subdivisão de Genética, em colaboração com a Secção de Café, do Instituto Agronômico, um extenso plano de estudos, que vem sendo executado desde 1935. Nos próximos capítulos serão dados alguns dos resultados obtidos, esclarecendo-se, ao mesmo tempo, quais as perspectivas para o cultivo dêste novo tipo de café em São Paulo.

\section{3-DESCRIÇÃO BOTÂNICA}

Os exemplares do cafeeiro " 387 " existentes em Campinas são representados por vários enxertos feitos sôbre o café excelsa em 1935 e anos subsequentes. Os enxertos mais antigos têm já três a quatro metros de altura e apresentam uma forma quase cilíndrica (est. 1).

A descrição botânica que se segue foi baseada em caracteres dêsses enxertos.

a) Ramos - laterais primários opostos, longos ; os inferiores atingem considerável comprimento, estendendo-se pelo chão, de modo a cobrir boa área de terreno ao redor da planta. Fazem um ângulo médio de 57,5 graus (extremos 42 a 76) com a haste principal. Os ramos secundários, terciários e de ordem inferior são abundantes. A haste principal e os ramos são cobertos por casca acinzentada e meio rugosa.

b) Fôlhas - breve-pecioladas, quando novas de uma côr bronze-escura meio esverdeada; fôlhas maduras de $213 \pm 1,70 \mathrm{~mm}$ de comprimento e $125 \pm 1,37 \mathrm{~mm}$ de largura, de um verde bem carregado, face superior brilhante, e inferior mais clara e sem brilho, persistentes, coriáceas, no geral elípticas e algumas quase circulares, ápice acuminado, base obtusa, lâmina e margem quase lisas ou muito pouco onduladas, com nervuras primárias de cada lado da nervura mediana (est. $3-A$ ) ; domácias de tamanho médio, pouco salientes na superfície superior, com orifício pequeno de forma va-

QUadro 1.-Medições das várias partes de 100 fôlhas do cafeeiro " 387 "

\begin{tabular}{|c|c|c|c|c|c|c|c|c|}
\hline \multirow[b]{2}{*}{$\begin{array}{c}\text { Valores } \\
\text { observadas }\end{array}$} & \multicolumn{5}{|c|}{$\begin{array}{llllll}L & \mathbf{a} & \mathbf{m} & \mathbf{i} & \mathbf{n} & \mathbf{a}\end{array}$} & \multicolumn{2}{|c|}{$\begin{array}{l}\text { Nervuras } \\
\text { primárias }\end{array}$} & \multirow{2}{*}{$\begin{array}{c}\text { Compri- } \\
\text { mento } \\
\text { do } \\
\text { pecíolo }\end{array}$} \\
\hline & $\begin{array}{l}\text { Compri- } \\
\text { mento } \\
\text { total }\end{array}$ & $\begin{array}{l}\text { Largura } \\
\text { máxima }\end{array}$ & Indice & $\begin{array}{l}\text { Compri- } \\
\text { mento } \\
\text { do ápice }\end{array}$ & $\begin{array}{l}\text { Ângulo } \\
\text { da base }\end{array}$ & Número & $\begin{array}{c}\text { Angulo } \\
\text { com a } \\
\text { nervura } \\
\text { central }\end{array}$ & \\
\hline & $m m$ & $m m$ & nuimero & $m m$ & Graus & numero & Graus & $m m$ \\
\hline Médias & $213,0 \pm 1,7$ & $125,5 \pm 1,4$ & $1,7 \pm 0,01$ & $13,1 \pm 0,5$ & $114,0 \pm 0, \theta$ & $7,5 \pm 0,1$ & $59 \pm 0,4$ & $16,6 \pm 0,3$ \\
\hline Extremos ... & $150,0-270,0$ & $52,0-159,0$ & $\cdots$ & $\ldots \ldots$ & $83-134$ & . & $\ldots \ldots$ & $\cdots$ \\
\hline
\end{tabular}


riável na face inferior, quase sempre provido de alguns pêlos nos bordos (est. 3-B). As dimensões são as mencionadas no quadro 1 e foram tomadas de modo idêntico ao que se empregou para as variedades de $C$. arabica, em trabalho publicado em Boletim Técnico dêste Instituto (6).

c) Estípulas - interpeciolares, deltóides, pouco acuminadas, com ponta de comprimento variável.

d) Flores - grandes, em glomérulos axilares, 1 a 4 flores por glomérulo (est. 4- $A$ ) e 1 a 7 glomérulos por axila, protegidos por calículos que podem encerrar apenas 1 glomérulo ou 1 principal e 2 secundários; calículo constituído por 2 a 3 pares de bractéolos e 2 a 3 pares de estípulas interpeciolares; o primeiro par de bractéolos muito reduzido; o par médio, de natureza foliar e muito variável em tamanho, e o mais interno, rudimentar ou mesmo ausente em alguns casos ; pedicelo curto, ovário ínfero, bilocular, cada loja normalmente com um só óvulo; cálice rudimentar, formado por 5 insignificantes dentículos; nectário discóide, grande; corola branca, de perfume agradável, constituída por 5 pétalas unidas na base, formando um tubo ; lobos da corola lineares, acuminados, estendidos ; estames em número de 5, exertos; filamento curto, fixo no tubo da corola junto ao ponto de separação dos seus lobos; inserção do filamento no têrço inferior da antera; estilo com 2 lobos estigmáticos, com papilas estigmáticas internas (est. 2- $A$ e est. 4- $B$ ). Os órgãos apresentam as dimensões mencionadas no quadro 2.

QUADro 2.-Dimensões das flores do cafeeiro "387". Amostra de 50 exemplares

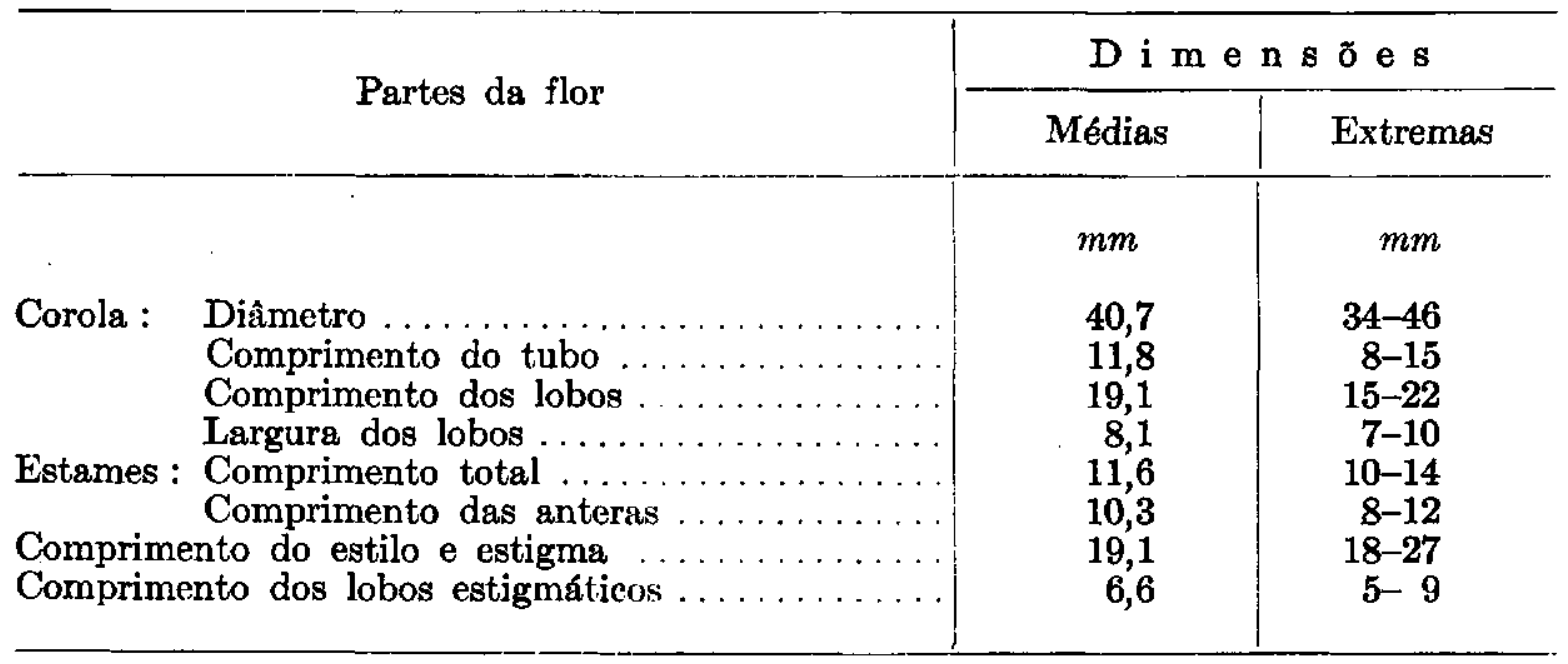

e) Fruto - oval-elíptico, vermelho bem escuro quando maduro, em média com 18,9 mm $(16,0-21,5 \mathrm{~mm})$ de comprimento e $14,9 \mathrm{~mm}(13,0-$ $17,0 \mathrm{~mm}$ ) de largura ; mesocarpo carnoso e endocarpo espêsso e bastante resistente (est. $2-B$ e $4-C$ ).

f) Semente - oblonga, plano-convexa, em média de $11,7 \mathrm{~mm} \ldots$ $(10,0-13,3 \mathrm{~mm})$ de comprimento e $7,4 \mathrm{~mm}(6,8-8,0 \mathrm{~mm})$ de largura (est. 4-D), verde-escura ou amarela, coberta por uma película esverdeada e muito aderente ; endosperma córneo ; embrião branco, pequeno, com dois cotilédones orbiculares justapostos e radícula curta e espêssa. 


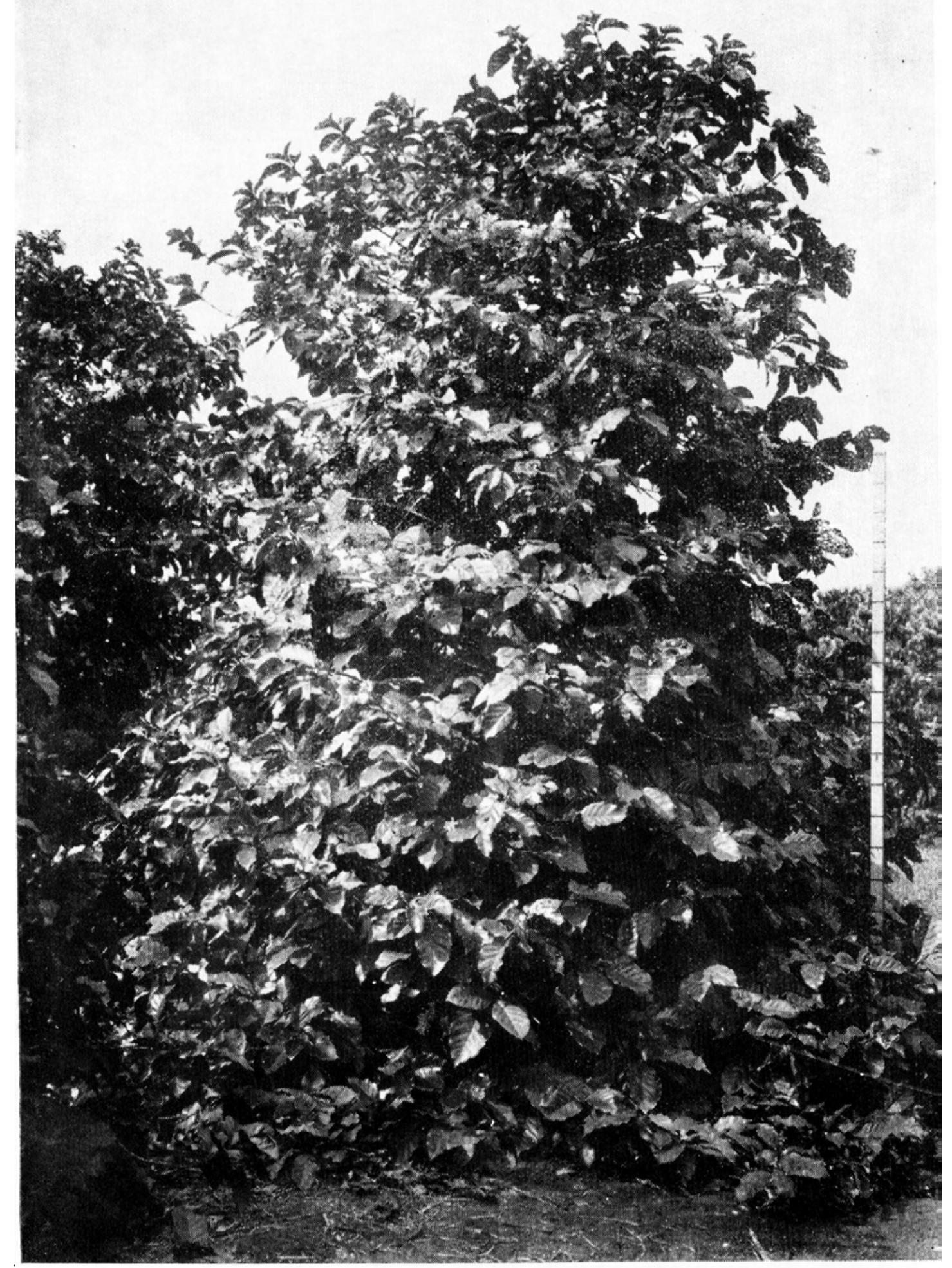

Enxêrto, com 10 anos, do cafceiro "387" da coleção da Fistação lixpcrimental Central de Campinas. 

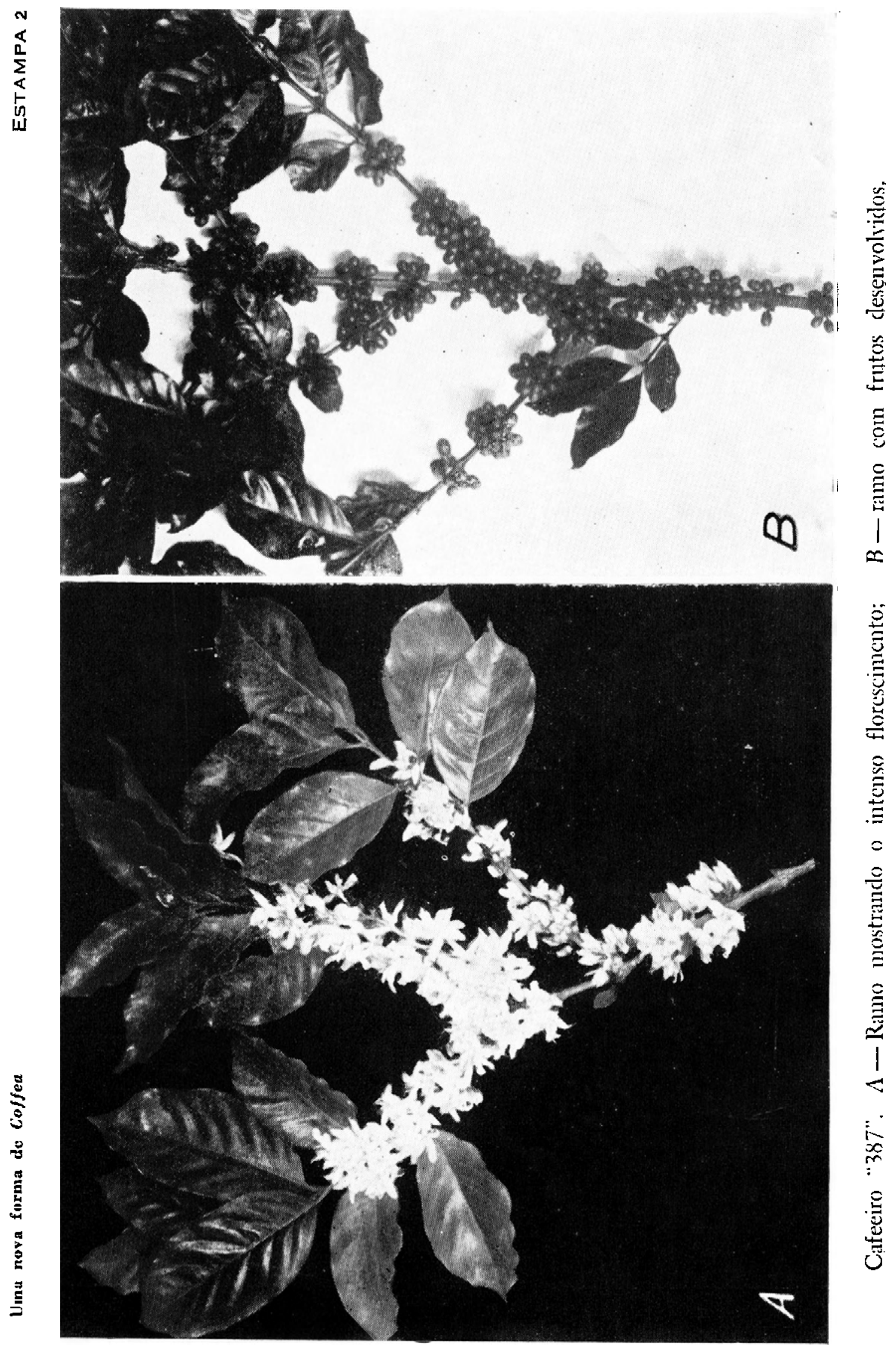


\section{4-AUTO-ESTERILIDADE}

Como já foi atrás mencionado, devido à grande produtividade da planta. original, que se encontrava rodeada apenas por plantas bourbon da espécie C. arabica, supôs-se, de início, que o cafeeiro " 387 " constituísse uma variação autofértil. Observações posteriores, entretanto, não vieram confirmar tal suposição.

Logo que os primeiros enxertos começaram a florescer, procedeu-se à autopolinização artificial das flores, protegendo-as, como se usa para o cafeeiro arábica, com sacos de papel (3). Apesar de se terem assim protegido cêrca de 3000 flores, em vários anos e épocas, apenas um total de 77 frutos foi até hoje obtido, muitos dos quais contendo uma só semente, o que indica ser êsse cafeeiro pràticamente auto-estéril.

A fim de se verificar se o tamanho muito longo do estilo da flor seria, em parte, responsável por êsse insucesso na autopolinização, resolveu-se empregar a técnica da "autopolinização auxiliada". Esta consiste no seguinte : após a abertura das flores dentro do saco de papel, êste é cuidadosamente aberto na extremidade, e, com uma pinça, retiram-se algumas corolas com seus respectivos estames, cujo pólen é colocado sôbre os estigmas tanto destas flores como das flores vizinhas do mesmo ramo protegido. O saco de papel, após esta operação, é novamente fechado. Este processo começou a ser empregado em 1945, não fornecendo, ao que parece, melhores resultados, apesar do excesso de pólen que foi colocado sôbre cada estigma. Em 1946, de 973 flores assim polinizadas, colheram-se apenas 16 frutos $(1,6 \%)$, ao passo que 1019 flores, apenas protegidas com sacos de papel, forneceram 4 frutos $(0,4 \%)$. Essa percentagem corresponde ao número de frutos desenvolvidos em relação ao número de flores. A percentagem de sementes obtidas, em relação ao número de lojas do fruto, é muito menor, devido à ocorrência de elevado número de sementes do tipo moca e de sementes chochas. A fim de se favorecer a queda do pólen no estigma da flor, usou-se também o processo de sacudir fortemente, e por algum tempo, o ramo coberto pelo saco de papel, após a verificação de que tôdas as flores do ramo se achavam abertas. Êste processo é mais simples e oferece menos possibilidade de contaminação; a sua eficiência, entretanto, ainda não foi determinada.

Finalmente, tentou-se fazer o cruzamento entre flores de diferentes enxertos, pertencentes ao mesmo clone, o que também corresponde a uma autopolinização. A técnica adotada nesses cruzamentos foi a já descrita em outra publicação (3). De 24 flores foram obtidos 6 frutos $(25 \%)$ e, dêstes, 7 sementes, não se sabendo como explicar tal percentagem de frutificação, bem mais elevada do que a obtida nos casos atrás descritos. Esses cruzamentos serão oportunamente repetidos.

Do exposto se pode concluir que a planta " 387 " é pràticamente autoestéril, o que representa uma séria dificuldade no seu aproveitamento econômico. 


\section{5-CONSTITUIÇÃO CITOLÖ:ICA}

Constituindo, sem dúvida, material valioso para pesquisas teóricas e de interêsse prático, mister se fêz examinar a constituição citológica dêsse cafeeiro $(\mathbf{1 0})$.

Procedeu-se preliminarmente ao enraizamento de estacas, tendo-se verificado, nas raízes obtidas, que se trata de uma planta com o mesmo número de cromosômios $(2 n=44)$ que a maioria das variedades de $C$. arabica, ou seja o dôbro do número encontrado êm $C$. Dewevrei $(2 \mathrm{n}=22)$, espécic com a qual muito se assemelha.

Tratar-sc-ia de uma mutação tetraplóide de C. Dewevrei? Dois rumos tomaram as pesquisas com o fim de esclarecer esta questão: a) duplicação dos cromosômios de $C$. Dewevrei, numa tentativa de produzir tetraplóides semelhantes ao "387", tetraplóides que deveriam cruzar-se com o " 387 "; e b) estudo da moiose.

A experiência de duplicação dos cromosômios foi realizada com sementes de C. Dewevrei var. excelsa $(\mathbf{8}, \mathbf{9})$. Alguns indivíduos tetraplóides foram obtidos; nenhum dêles, no entanto, se aproximou, morfològicamente, do " 387 ". Estes tetraplóides produzem muito poucos frutos, e seu cruzamento com o " 387 " é difícil.

O estudo da meiose do "387" (10) revelou que há formação de uni--, bi-e trivalentes na prófase. Êstes últimos são pouco frequentes. Em mctáfase, tendo-se examinado um número maior de células, verificou-se ainda a existência de raros tetravalentes. Da anáfase I, irregular, resultam dois grupos de cromosômios com números variáveis (desde 16 até 28), atrasando-se alguns cromosômios, no movimento, e se perdendo no citoplasma, sem se incluir em qualquer dos dois grupos. Nos núcleos resultantes da anáfase II, examinados em menor número, encontraram-se de 15 a 23 cromosômios. Os micrósporos resultantes de uma meiose assim anormal têm $\mathbf{n}=$ 15 a 28 cromosômios, sendo mais frequentes $(80 \%)$ aquêles que têm $\mathrm{n}=20$ a 24 ; dentre êstes, $36 \%$ têm $\mathrm{n}=22$.

O pólen é variável em tamanho, sendo provàvelmente maiores os grãos de pólen que têm maior número de cromosômios ; os menores diferem ainda no aspecto, apresentando-se muito dêles malformados e colorindo-se fracamente em relação aos demais.

O comportamento da meiose não é, assim, típico de um auto-tetraplóide.

A formação de univalentes sugere tratar-se de um híbrido (7). Neste caso, desde que a planta se cruza com facilidade com as variedades de $C$. arabica, pode-se imaginar que as espécies que entraram em sua composição tenham sido $C$. Dewevrei e C. arabica.

Um híbrido entre estas espécies seria triplóide $(2 \mathrm{n}=33)$. Como a planta “ 387 " é tetraplóide $(2 \mathrm{n}=44)$, provàvelmente contém 22 cromosômios arabica e 22 de Dewevrei, êstes últimos originados de um gâmeta não reduzido. 


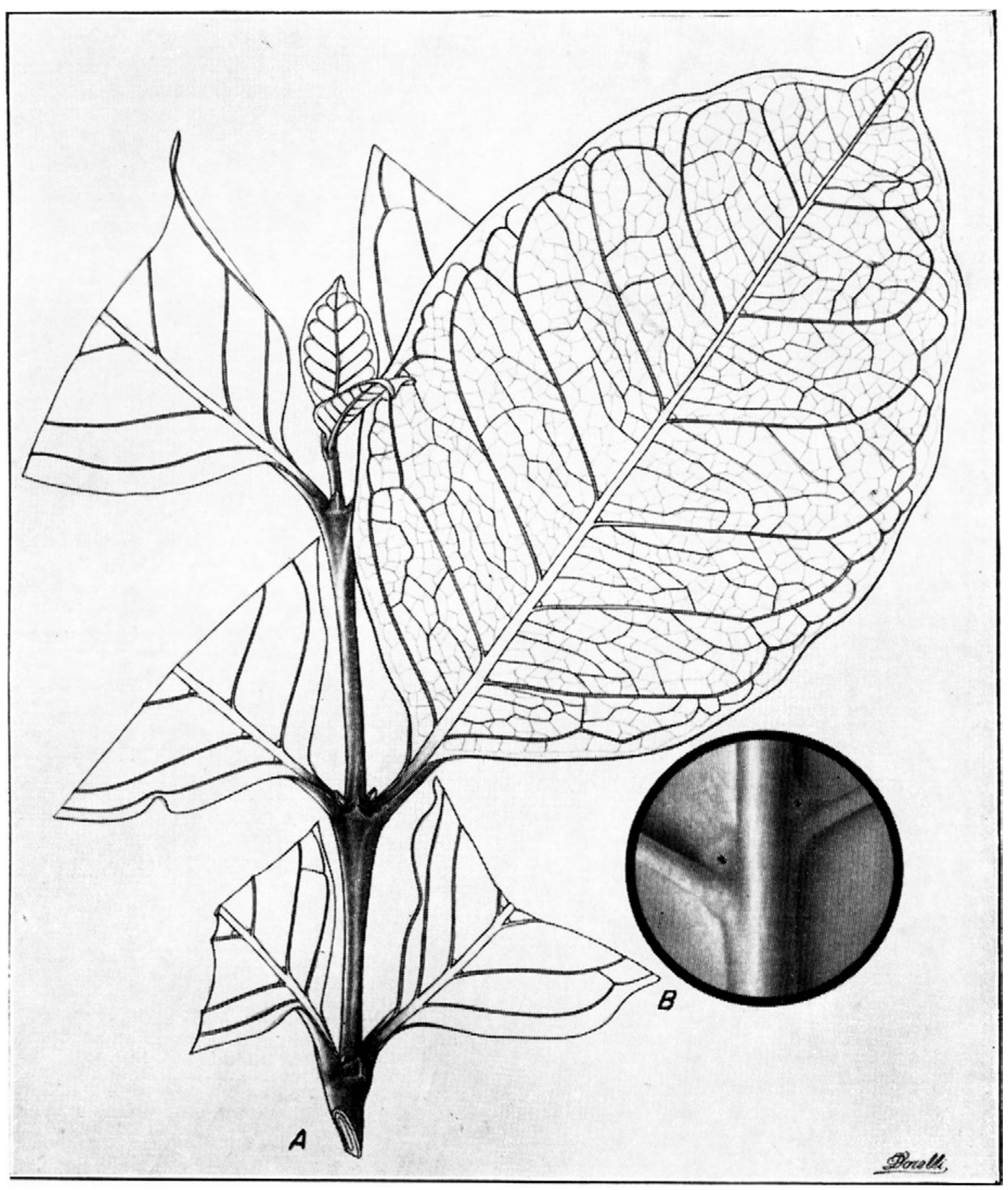

A, Ramo do cafeeiro "387", mostrando particularidades da fôlha, metade do tamanho natural; $B$, domácia, $x 4$. 


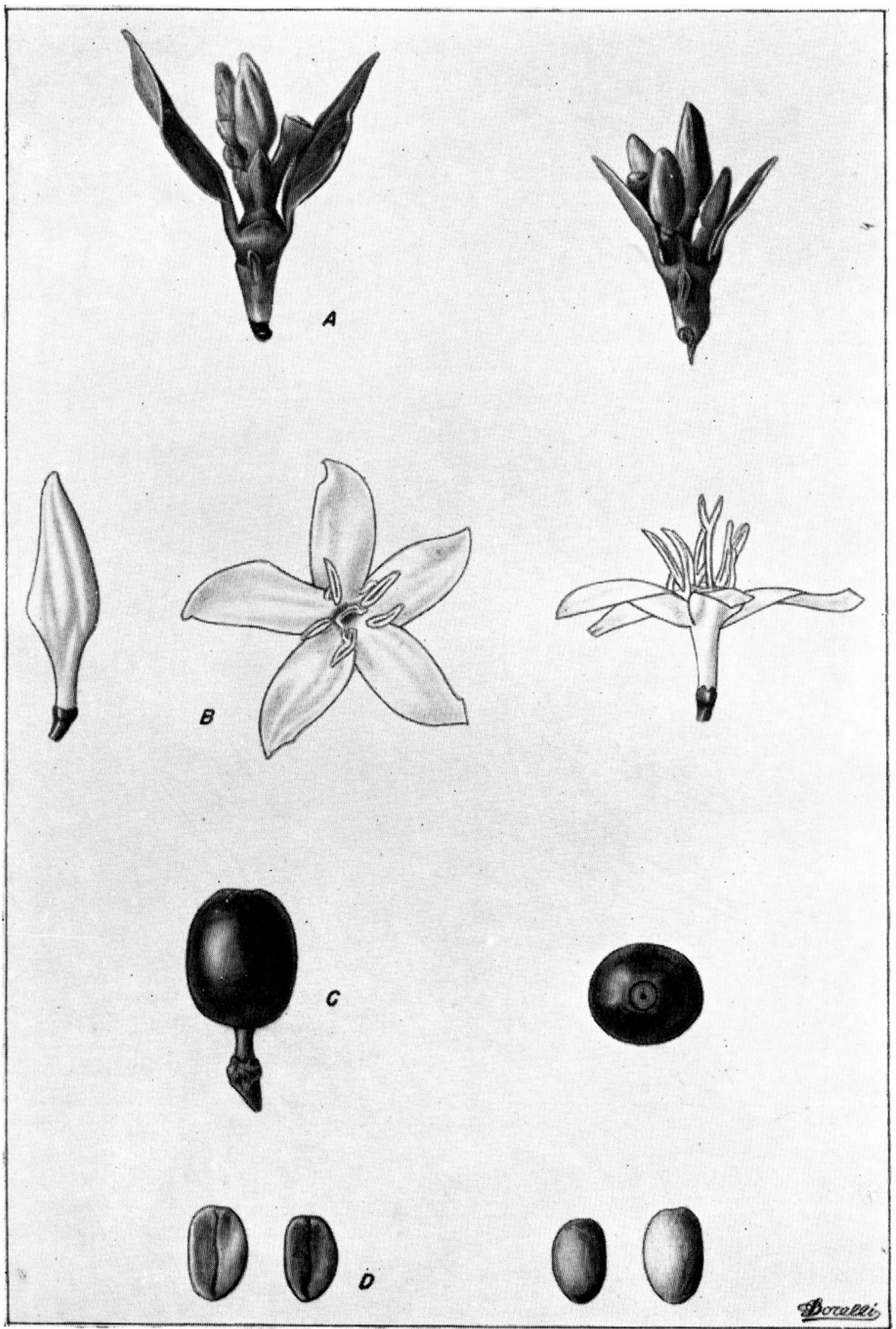

Caraterísticos da planta "387": A, inflorescència, mostrando o calículo, as estípulas interpcciolares e bractéolos foliáceos $\left(\mathrm{x}_{2}\right) ; \mathrm{B}$, flores, tamanho natural; $\mathrm{C}$, frutos, tamanho natural; $D$, sementes com c sem pergaminho, tamanho natural. 


\section{6-INFORMAÇÕES PRELIMINARES SÔBRE A CONSTITUIÇĀO GENETICA}

Outro estudo de interêsse básico é o da análise genética dêsse cafeeiro. Pela autopolinização artificial, infelizmente, poucos indivíduos têm sido obtidos, os quais, entretanto, diferem entre si em, praticamente, todos os caracteres, desde o porte até as dimensóes e coloração das fôlhas, frutos e sementes. Os descendentes assim obtidos também revelaram ser pràticamente auto-estéreis.

Um extenso projeto de hibridações vem sendo conduzido desde 1937, tendo-se cruzado o cafeeiro "387" com espécies diplóides de Coffea, com alguns de seus tetraplóides artificiais, com uma série de genótipos do $C$. arabica (TT; NaNa; na na; pr pr; Fs Fs; br br;Ct Ct; ce ce; ErEr; $C$-; mo mo; $M g M g$ ) e com os próprios descendentes do " 387 ", obtidos, seja pela polinização artificial, seja pela natural. Além disso, realizaram-se numerosos cruzamentos entre os híbridos obtidos, bem como diversos "backerosses" seguidos. Fizeram-se igualmente detalhadas observações numa série de híbridos espontâneos dessa planta. De modo geral, forneceram melhores resultados as hivridações com os diversos tipos de $C$. arabica, tendo sido ínfimo o sucesso dos cruzamentos com as espécies diplóides e mesmo com os seus autotetraplóides. Assim, por exemplo, êstes últimos cruzamentos apenas forneceram três híbridos (de um total de 601 flores artificialmente castradas e polinizadas) cujo número de cromôsomios é de $2 \mathrm{n}=33,43$ e 44 , respectivamente. Dos cruzamentos com C. arabica (mais de 2000 flores polinizadas) obteve-se um total de 364 plantas, das quais a maioria já se acha em plena produção. Essas hibridações foram efetuadas nos dois sentidos, obtendo-se uma percentagem de frutificação ligeiramente superior $(31,5 \%)$ quando se aplicou o pólen do " 387 " nas flores do $C$. arabica, do que quando se realizou o cruzamento recíproco $(22,7 \%)$.

Visando a obtenção de formas autoférteis, sem perda apreciável dos caracteres favoráveis do "387", os híbridos $F_{1}$ ("387" x $C$. arabica) têm sido cruzados com $C$. arabica; e dêsses "backcrosses", novamente hibridados com esta espécie, obtiveram-se, em uma planta, pela autopolinização artificial, atê $69 \%$ de frutificação.

Apesar de só existirem dados preliminares, poder-se-ão deduzir as seguintes conclusões gerais sôbre a constituição genética do cafeeiro "387" :

a) planta " 387 " é extremamente heterozigota com relação aos fatôres determinantes dos seus principais caracteres morfológicos.

b) Nos híbridos “ 387 ” $\mathrm{x}$ C. arabica, nota-se predominância dos caracteres do " 387 ", fato já observado nas mudas novas, quando apenas acusam alguns pares de fôlhas. Esta predominância se nota ainda nos "backcrosses" (primeiro e segundo) com o C. arabica.

c) Dos cruzamentos realizados com os genótipos de $C$. arabica, pode-se dizer que o "387" deve possuir o alelo $b r$ desta espécie, pois, de todos os cruzamentos com plantas arábica de brotos verdes, de constituição $b r b r$, resultam $36 \%$ de plantas com essa coloração. Também deve possuir o alelo $N a$, pois as plantas $\mathrm{F}_{1}$, do cruzamento com a var. nana ( $n a n a$ ), se mostram com aspecto de murta ( $\mathrm{Na} n a)$. Os alelos dominantes dos fatôres purpu- 
rascens e laurina devem também estar presentes, visto não surgirem plantas com êsses caraterísticos nas populações $F_{1}$.

d) Pelas classificações das sementes obtidas, seja pela autofecundação artificial, seja pelos cruzamentos com genótipos de $C$. arabica com endosperma verde e amarelo, conclui-se que o cafeeiro "387" também possui o alelo cêra, provàvelmente originário de $C$. Dewevrei.

e) Os gens dominantes do arábica, fasciado $(F s)$, caturra $(C t)$, calycanthema $(C)$, se mostram com a mesma intensidade no $\mathbf{F}_{1}$.

f) Quanto aos fatôres determinantes da forma da planta, e da ocorrência de "saia" (ramos inferiores muito longos), o cafeeiro "387" parece também ser heterozigoto.

\section{7-IMPORTÂNCIA ECONŌMICA}

\section{1-PRODUTIVIDADE, TIPO DE SEMENTES PRODUZIDAS E QUALIDADE DA BEBIDA}

A rusticidade e a elevada capacidade de produção do " 387 ", qualidades que chamam desde logo a atenção dos que o examinam, contribuiriam para tornar êsse cafeeiro de importância econômica excepcional, não fôsse o defeito de auto-esterilidade que apresenta.

Os enxertos mais antigos, existentes na Estação Experimental Central de Campinas, pertencem a duas séries, plantadas, respectivamente, em 1936 (enx. 2 a enx. 6) e 1937 (enx. 7 a enx. 16). Encontram-se na coleção de cafeeiros, nas proximidades de outras espécies, tais como C. Deweurei, C. canephora e C. arabica.

As suas primeiras produções não foram anotadas, individualmente, para cada enxêrto, sendo as sementes apenas aproveitadas para provas de qualidade do café. Sòmente mais tarde, as anotações relativas à produtividade começaram a ser feitas para os enxertos individuais. Para o período 1945/49, as produçбes, em frutos maduros, foram as mencionadas no quadro 3 .

O que surpreende é a variabilidade de produção entre enxertos da mesma idade (entre os da série enx. 2 a enx. 6 e enx. 7 a enx. 16), pois o solo onde se encontram todos êsses cafeeiros é bem uniforme. Demais, todos êles se acham igualmente expostos ao vento e à visita de insetos. $\mathrm{O}$ único fato variável é o porta-enxêrto, neste caso, pertencente à var. excelsa de C. Dewevrei. Esta variedade é também auto-estéril e as sementes colhidas, e de fecundação não controlada, devem ter dado progênie muito variável, o que talvez explique a variação notada na produção dos enxertos.

Quanto às sementes produzidas pelo " 387 ", nota-se que é muito baixa (menos de 0,1\%) a percentagem de sementes do tipo concha (duas sementes em uma loja do fruto) e muito mais elevadas (60\%) as percentagens de sementes do tipo moca ou seja uma única semente por fruto, e sementes chochas $(16 \%)$. Nos frutos maduros, as sementes denominadas chochas são constituídas por vestígios de película prateada, às vêzes acompanhada de quantidades variáveis de tecido, provàvelmente de endosperma, encerrando ou não um pequeno embrião. As lojas dos frutos onde se encontram essas sementes são, porém, normalmente desenvolvidas. Como consequência da 
Quadro 3.- Produções individuais dos enxertos do cafeeiro '387', de 1945 a 1949, e a produção média, nesse período

\begin{tabular}{|c|c|c|c|c|c|c|}
\hline \multirow{2}{*}{$\begin{array}{l}\text { Número dos enxertos } \\
\text { do cafeeiro " } 387 \text { " }\end{array}$} & \multicolumn{5}{|c|}{ Produção de frutos maduros nos anos } & \multirow{2}{*}{$\begin{array}{l}\text { Produção } \\
\text { média de } \\
5 \text { anos } \\
1945-49\end{array}$} \\
\hline & 1945 & 1946 & 1947 & 1948 & 1949 & \\
\hline & $\mathrm{kg}$ & $k g$ & $\log$ & $k g$ & $\mathrm{~kg}$ & $k g$ \\
\hline 2 & 29,5 & 33,3 & 8,5 & 58,0 & 1,5 & 26,2 \\
\hline 3 & 44,0 & 20,2 & 38,4 & 38,8 & 10,4 & 30,4 \\
\hline 4 & 22,1 & 23,3 & 24,3 & 50,7 & 8,3 & 25,7 \\
\hline 5 & 37,4 & 15,2 & 43,5 & 39,4 & 12,8 & 30,0 \\
\hline 6 & 25,8 & 20,6 & 29,1 & 49,5 & 5,0 & 26,0 \\
\hline 7 & 18,7 & 17,3 & 16,7 & 35,6 & 0,1 & 17,7 \\
\hline 8 & 19,2 & 11,8 & 28,9 & 34,0 & 12,8 & 21,3 \\
\hline 9 & 16,5 & 10,5 & 24,4 & 25,4 & 2,8 & 15,9 \\
\hline 10 & 19,4 & 5,5 & 18,9 & 25,0 & 2,1 & 14,2 \\
\hline 11 & 1,5 & 26,0 & 7,8 & 40,9 & 3,4 & 15,9 \\
\hline 12 & 12,3 & 12,0 & 9,9 & 26,5 & 0,8 & 12,3 \\
\hline 13 & 14,6 & 27,9 & 5,4 & 38,4 & 3,0 & 17,9 \\
\hline 14 & 11,8 & 22,7 & 7,0 & 37,4 & 1,7 & 16,1 \\
\hline 15 & 17,6 & 12,8 & 24,1 & 32,0 & 10,7 & 19,4 \\
\hline $16 \ldots \ldots \ldots$ & 18,1 & 10,8 & 28,8 & 27,3 & 16,5 & 20,3 \\
\hline Média. & 20,6 & 18,0 & 21,0 & 37,3 & 6,1 & 20,6 \\
\hline
\end{tabular}

elevada percentagem de sementes moca e chocha, o rendimento (isto é, a relação do pêso de frutos maduros para o de sementes) é pouco satisfatório, cêrca de 10 , quase o dôbro do comumente verificado em cafeeiros arábica normais.

Entre as sementes consideradas normais, nota-se que nem sempre o endosperma é completamente desenvolvido. Também são frequentes casos em que há uma considerável diferença no tamanho das sementes normais de um mesmo fruto.

Todos êstes defeitos devem estar, pelo menos, parcialmente correlacionados com as anomalias citológicas verificadas durante a meiose. Se as mesmas irregularidades constatadas na microsporogênese ocorrerem, também, na macrosporogênese, uma parte dos óvulos deve ser estéril. Que isto realmente se dá, comprova-se pelo fato de ser ainda muito alta a percentagem $(74 \%)$ de sementes moca, mesmo nos cruzamentos com C. arabica, quando se usa abundante pólen normal. Quanto às sementes chochas, presume-se que elas também sejam devidas a cruzamentos espontâneos interespecíficos que ocorrem nas plantas " 387 " da coleção de Campinas, pois, como já foi dito, elas se encontram bem próximas de vários outros cafeeiros diplóides e tetraplóides. A fim de se examinar essa questão, as sementes colhidas em 1947, de cruzamentos entre o “387" e plantas arábica e plantas canephora tetraplóides, foram cuidadosamente examinadas com relação à ocorrência dessa anomalia. Os resultados estão no quadro 4. 
QuAdro 4.- Número total de sementes e percentagens de sementes chochas obtidas em cruzamentos do " 387 " com variedades de C. arabica e com C. canephora tetraplóide

\begin{tabular}{|c|c|c|c|}
\hline \multirow{2}{*}{$\begin{array}{c}\text { Espécies } \\
\text { cruzadas com o "387" }\end{array}$} & \multicolumn{2}{|c|}{ Número de sementes } & \multirow{2}{*}{$\begin{array}{l}\text { Percentagem } \\
\text { de sementes } \\
\text { chochas }\end{array}$} \\
\hline & Total & Chochas & \\
\hline & $N .^{\circ}$ & $N .^{\circ}$ & $\%$ \\
\hline C. arabica (diversas variedades) & 393 & 15 & 3,8 \\
\hline C. canephora (tetraploide) & 131 & 34 & 25,9 \\
\hline
\end{tabular}

Por aí se conclui que, mesmo nos cruzamentos com formas tetraplóides, de $C$. canephora, a percentagem de sementes chochas foi bem elevada.

Foram também colhidas amostras de frutos de vários enxertos do " 387 ", que se acham plantados intercaladamente entre fileiras da variedade bourbon e isolados de outras espécies. Nestes frutos notou-se que a percentagem de sementes chochas atingiu 9,6\%. Uma abundante quantidade de pólen normal de $C$. arabica, embora provàvelmente não contribua para uma sensível diminuição da percentagem de sementes moca, deverá contudo reduzir a quantidade de sementes chochas, melhorando, consequentemente, o "rendimento".

Quanto à côr, as sementes normalmente produzidas pelo cafeeiro " 387 ", aparentemente, possuem um aspecto esverdeado. Esta côr é uma consequência da película que as reveste e que, neste cafeeiro, se apresenta esverdeada e muito aderente. Retirando-se a película, o que se consegue umedecendo as sementes, observa-se que elas se classificam em sementes claras (tipo cêra) e esverdeado-escuras, de diversas tonalidades. A percentagem média de sementes claras é de $23,6 \%$. De dois modos se explica o aparecimento de sementes claras. Parte delas, obtidas de flores de polinização aberta, sem contrôle algum, pode ser resultado de autofecundação natural, pois a planta é heterozigota para fatôres que controlam a côr das sementes. Outra porção de sementes claras, muitas vêzes malconformadas, pode representar cruzamentos entre o " 387 " e outros cafeeiros pertencentes à espécie C. Dewevrei, os quais possuem sementes de côr cêra e se acham próximos aos enxertos do "387". As sementes esverdeadas de várias tonalidades representam, por sua vez, o resultado da segregação ou de cruzamentos com $C$. canephora ou C. arabica. Estas espécies são portadoras de sementes verdes e se acham próximas do "387", na coleção de Campinas.

Os frutos maduros são fàcilmente despolpados, e o "pergaminho" (endocarpo) é bastante espêsso.

Amostras de sementes foram remetidas a algumas casas exportadoras de café de Santos, tais como American Coffee Corporation, Prado Chaves e La Domus \& Cia. e outras, a fim de se obter a opinião dos especialistas quanto ao aspecto e quanto à bebida do " 387 ". 'Em geral, tôdas as firmas 
estranharam o aspecto do café, dizendo-o desconhecido em Santos. A película aderente impressionou desfavoràvelmente. A classificação da bebida foi desde "estritamente mole", "softish", "dura", até mesmo "riada". Não houve concordância, mas verificou-se que os provadores não acharam um gôsto acentuadamente diferente do fornecido pelo $C$. arabica, pois que alguns disseram ser possível a sua utilização para a composição de misturas (blends). E incontestável que o gôsto dêste café é incomparàvelmente superior ao dos que são produzidos pelas diversas variedades de $C$. Dewevrei. Constitui, portanto, uma reserva de que se poderá lançar mão, caso haja escassez de café e seja difícil reconstituir as antigas zonas cafeeiras com o C. arabica.

E provável que o produto resultante do cruzamento do " 387 " com C. arabica dê uma bebida melhor, pois o endosperma é produto da dupla fertilização.

\section{2-PROPAGAÇÃO PELA ENXERTIA}

Sendo muito variável a descendência do cafeeiro " 387 ", o único meio de multiplicá-lo em larga escala só pode ser por via vegetativa. Tem sido empregada para essa finalidade ùnicamente a enxertia. A estaquia vem sendo estudada, porém, ainda em fase experimental.

Dois tipos de enxertia foram usados: o de fenda simples e o de fenda lateral. $O$ primeiro foi empregado até recentemente e exigia que houvesse sempre viveiros de porta-enxertos em tamanho apropriado, porque a operação tinha de ser sempre realizada em parte ainda verde do porta-enxêrto (11). A enxertia de fenda lateral permite o emprêgo de porta-enxertos mais amadurecidos, e apresenta a grande vantagem de poder ser feita numa mesma altura, o que proporciona maior uniformidade, nos indivíduos enxertados (12).

O porta-enxêrto usado tem sido o excelsa, variedade muito rústica de C. Dewevrei, com 22 cromosômios somáticos e os próprios descendentes do “387", após escolha dos tipos que mais se aproximam, no aspecto vegetativo, a êsse cafeeiro.

A fim de se aumentar o material disponível de ramos ortotrópicos, para enxertia, foi feita uma grande série de enxertos dêsse tipo de ramos, os quais foram deixados no viveiro, em canteiros bastante estercados e protegidos pela sombra parcial de um ripado. Nesse ambiente propício para um rápido desenvolvimento, os ramos ortotrópicos enxertados em pouco tempo puderam ser aproveitados para novas multiplicações. Cortado o ponteiro, desenvolve-se uma gema de ramo ortotrópico na axila de cada uma das fôlhas terminais, multiplicando assim, rà pidamente, o número de ponteiros disponíveis para enxertia. Dessa maneira, o cafeeiro " 387 " pode ser multiplicado em larga escala e usado em várias plantações em diferentes pontos do Estado de São Paulo, principalmente em zonas reconhecidas como produtoras de café de boa qualidade. 


\section{3-PLANTAÇÕES INTERCALARES DO CLONE "387" (OU DE CLONES DERIVADOS DE SEUS DESCENDENTES) COM $C$. ARABICA}

Considerando que o cafeeiro " 387 " é auto-estéril e, além disso, extremamente heterozigoto, a sua descendência obtida por meio de sementes não é econômicamente aproveitável. Já vimos, porém, que é fácil enxertá-lo, e que o clone assim obtido apresenta grande uniformidade. Uma plantação monoclonal, entretanto, estaria fadada a completo insucesso, pois a produção seria pràticamente nula, em virtude da auto-esterilidade. A fim de se obterem boas produçбes, deve-se, pois, recorrer a um artifício, semelhante ao já largamente empregado em Java, nas plantações de clones de C. canephora, que também são auto-estéreis. O problema consiste, simplesmente, em prover o clone " 387 " de um bom agente polinizador, o que se consegue interplantando fileiras de um outro tipo de café que floresça ao mesmo tempo. Como o " 387 " se cruza fàcilmente com C. arabica, vêm sendo estabelecidas, em várias das Estações Experimentais do Instituto Agronômico, pequenas plantações mistas, plantando-se, em linhas alternadas, o - clone "387" e uma linhagem de bourbon altamente produtiva. Tais plantações ainda são novas, não permitindo conclusões definitivas. Notou-se, porém, que o clone "387" floresceu mais tardiamente que o bourbon, devendo-se, por êsse motivo, também tentar como agente polinizador a var. semperflorens (Coffea arabica L. var. sempeflorens K.M.C.), que talvez ofereça maiores garantias de sucesso. Compreende-se fàcilmente que a colheita destas linhas deverá ser feita separadamente para o clone "387" e para o bourbon.

\section{4-PLANTAÇÕES INTERCALARES DO CLONE "387" COM UM OU MAIS CLONES DERIVADOS DE SEUS DESCENDENTES}

Como já ficou atrás exposto, numerosos cruzamentos foram realizados, a fim de se encontrarem formas compatíveis entre o " 387 " e seus derivados mais produtivos, com tipo semelhante de sementes. Tais formas seriam plantadas em linhas alternadas com o clone " 387 ", ocorrendo, assim, nestas culturas, a interpolinização recíproca. A principal vantagem dêsse tipo de consociação seria a possibilidade de se poder efetuar uma colheita comum de tôda a plantação ; mas a qualidade do café produzido no clone " 387 " provàvelmente seria inferior à da obtida nas plantações contendo o arábica como polinizador.

\section{5-PLANTAÇÕES DE DERIVADOS AUTOFÉRTEIS}

Um cafeeiro que, além de possuir as excelentes qualidades de produção e rusticidade do " 387 ", ainda fôsse autofértil, constituiria, sem dúvida, uma forma de excepcional interêsse econômico. Daf́ a preocupação que se vem tendo e o granda volume de trabalhos já efetuados, visando encontrar essa forma, quer nos descendentes do "387", obtidos pela polinização não controlada, quer nas populações derivadas de cruzamentos artificiais. Já se mencionou que, após alguns "backcrosses" com C. arabica, a autofertilidade tem aumentado sensìvelmente em algumas combinações, o que dá esperanças 
de se encontrar, futuramente, a forma desejada, a qual ainda deverá dar descendência uniforme não só no aspecto vegetativo, como na produção, antes de poder ser multiplicada em larga escala para distribuição aos lavradores do Estado.

\section{8-RESUMO}

Nos extensos trabalhos de melhoramento do cafeeiro, há 18 anos em realização na Subdivisão de Genética do Instituto Agronômico, tem-se dedicado especial atenção à espécie $C$. arabica $\mathrm{I}$., pelo fato de todos os nossos cafèzais pertencerem a esta espécie que, sem dúvida, fornece o produto de melhor qualidade. Nas regiões de terras extremamente cansadas, um dos principais fatôres levados em consideração no melhoramento é a rusticidade, caráter êsse, entretanto, encontrado de preferência em outras espécics, tais como o C. canephora e $C$. Dewevrei, cujos cafés são de má qualidade. A hibridação interespećfica, que poderia reunir em uma só planta caraterísticos de rusticidade e boa qualidade de bebida, tem o inconveniente de dar origem a plantas triplóides, que são estéreis. Daí se deduz que a obtenção artificial de formas que combinassem êsses caraterísticos constitui problema, cuja solução é extremamente demorada.

No presente trabalho, apresentam-se os caracteres de uma nova forma de Coffea, encontrada $\mathrm{cm}$ cafèzal da Fazenda Itaporã, cm Terra Roxa, município de Viradouro, que, com algumas ressalvas, oferece a desejada combinação de caracteres. Trata-se, provàvelmente, de um híbrido espontâneo entre $C$. arabica e $C$. Dewevrei, com $2 \mathrm{n}=44$ cromosômios, extremamente rústico e produtivo, cujas sementes fornecem uma bebida que pode ser classificada como boa. Apenas apresenta, como principal defeito, uma autoesterilidade quase completa.

Os seus caraterísticos botânicos são descritos em detalhe. Devido ao seu porte elevado, ramos abundantes e fôlhas grandes e coriáceas, êsse cafeeiro se assemelha ao $C$. Dewevrei. Os frutos são oval-elípticos, de um vermelho bem escuro quando maduros, e as sementes oblongas, constatando-sc elevada percentagem do tipo "moca" e "chocha".

Quanto à constituição citológica, as pesquisas conduziram à hipótesc de êste cafeeiro possuir 22 cromosômios de C. arabica e 22 (número diplóide) de $C$. Dewevrei, o que parece confirmado pelos resultados obtidos nas hibridações com C. arabica.

Apresentam-se também algumas informações preliminares sôbre a sua constituição genética, derivadas de um extenso projeto de cruzamentos com espécies e tamběm genótipos diferentes de C. arabica (nana; prpr; FsFs; lrlr ; momo; $\mathrm{MgMg} ; \mathrm{ErEr} ; \mathrm{C}-$; CtCt; cece; etc.). Concluiu-se que a nova forma é extremamente heterozigota, com rclação aos fatôres determinantes dos seus principais caracteres morfológicos, e que possui vários alelos dos fatôres conhecidos de $C$. arabica, apresentando os indivíduos $\mathrm{F}_{1}$, e os "backcrosses" com esta espécic, acentuada predominância dos caracteres da nova forma. A auto-esterilidade predomina nas gerações de "backcrosses" seguidos, já se tendo encontrado, entretanto, plantas razoàvolmente autoférteis. 
Além de constituir material básico de grande importância para as tentativas de síntese de novos tipos de cafeeiros, a forma em questão também está sendo ensaiada em plantações mistas, intercalando-se o seu clone (cafeeiros enxertados) com fileiras de cafeeiros arábica (bourbon, etc.), que servirão de agentes polinizadores.

Conclui-se que a descoberta dêsse cafeeiro, em Terra Roxa, facilitará a solução do problema da formação de novos cafèzais em terras extremamente esgotadas.

\section{SUMMARY}

In the past 18 years coffee breeding investigations by the Genetics Division of the Instituto Agronomico have been largeiy confined to the species $C$. arabica because it is the species that produces coffee of the best marketable qualitics.

Coffee cultivation in depleted soils requires the use of very vigorous plants. Vigorous plant growth is more frequently found in some diploid species of Coffea. Artificial hybridization of these diploid species with the tetraploid species C. arabica has been tried in several of the Institutes' Experiment Stations where breeding work on coffee is underway. Small seale breeding tests have also been carried out at Campinas for many years in which attempts have been made to combine the favorable qualities of plant vigor, as found in C. canephora and C. Dewevrei, with the good "cup qualities" of $C$. arabica. The results of these initial investigations indicate, however, that the obtaining of an interspecific hybrid suitable for use in the areas with depleted soils, would be very slow process.

The accidental finding of a new type of coffee on a plantation in Viradouro County, which, with few exceptions, offers the desired combinations of characters, is of special interest. It is the purpose in this paper, to describe the characteristics of the new type. of , coffee. The new type is believed to be a natural hybrid between $C$. arabica and $C$. Dewevrei. It has 44 chromosomes, is extremely vigorous and productive, and its seeds produce a beverage of reasonably good quality. Its principal defect is its almost complete self-sterility.

Detailed cytological observations have been made on the meiotic behavior of the chromosomes of the original new type coffee plant and several of its interespecific hybricks. These studies suggest the hypothesis that this new type coffee plant has 22 chromosomes of C. c.rabica (normal haploid number of this species) and 22 chromosomes (diploid number) of $C$. Deweurei.

$\Lambda$ large number of crosses have been made between this new type of coffee and different genotypes of C. arabica (nana ; $\mathrm{prpr} ; \mathrm{FsF}^{\mathrm{s} s}$; lrlr; momo; $\mathrm{MgMg} ; \mathrm{ErEr}$; $\mathrm{Cl}_{-}$; $\mathrm{ClCt}$; cece ; etc.). The results of these studies have furnished preliminary information on the genetic constitution of the new coffee type. It is heterozygous with respect to the genes which control its principal morphological characters; it has various alleles of the known genes of $C$. arabica, plants of the $\mathbf{F}_{1}$ generation and backcrosses with $C$. arabica show a predominance of the principal characters of the new type coffee plant. Self-sterility remains dominant in the progeny of the backcrosses but some plants have been found that have a reasonable degree of self-fertility.

This new type of coffee has a special value as a basis for the breeding and developing of new coffee types. It is also being tested in mixed plantings where it is established as a clone and planted in alternate rows of plants of $C$. arabica var. bourbon that serve as sources of pollen.

The finding of this new type of coffee greatly facilitates the possible development of still other coffee types that may prove to be even more satisfactory for use on depleted soils.

\section{LITERA'TURA CITADA}

1. Chevalier, A. Nouveau groupement des espèces du genre Coffea et spècialement des celles de la section Eucoffea. Comptes rendus de seances de l'Academie des Sciences de Paris 210 : 357-361. 1940. 
2. Krug, C. A. Contribuição para o estudo da citologia do gênero Coffea. Bol. Téc. do Instituto Agronômieo de Campinas 11: 1-8, fïg. 1-9. 1934.

3. Krug, C. A. Contrôle da polinização nas flores do cafeeiro. Bol. Téc. do Instituto Agronômico de Campinas 15: 1-12, fig. 1-8. 1935.

4. Krug, C. A. Melhoramento do cafeeiro. Doze anos (1933-1944) de pesquisas básicas e aplieadas, realizadas nas Seccões de Genética, Café e Citologia do Instituto Agronômico. Bol. da Super. dos Serv. do Café do Estado de São Paulo 20 : $863-872,979-992,1038-1046.1945$.

5. Krug, C. A. e A. Carvalho. Café -... Relatório da Seção de Genética do Instituto Agronotmico de Campinas. 1935-36. (Não publicado).

6. Krug, C. A., J. F. T. Mendes e A. Carvalho. Taxonomia de Coffea arabica I. Deserição das variedades e formas oncontradas no Estado de São Paulo. Bol. Tée. do Instituto Agronômieo do Campinas 62: 1-57, fig. 1 e 2. 1938.

7. Krug, C. A. e A. J. T. Mendes. Observaçóes citológicas em Coffea - IV. Bragantia $1: 467-48 \pi$, fig. 1-18. 1941 .

8. Mendes, A. J. T. Duplicação do número de cromosômios em café, algodão e fumo pela ação da colchicina. Anais da Primeira Reunião Sul-Americana de Botânica 3 : 331-349. 1938.

9. Mendes, A. J. T. Observações citológicas em Coffea. XI - Métodos de tratamento pela colchicina. Bragantia $i: 221-230$, est. 1.1947.

10. Mendes, A. J.'I. Observaçôes citológicas em Coffea. XII - Uma nova forma tetraplóide. Bragantia $9: 25-34$, est. 1, fig. 1. 1949.

11. Mendes, J. E. 'T. A enxertia do cafceiro - I. Bol. Téc. do Instituto Agronômico de Campinas $39: 1-18$, fig. 1-6. 1938.

12. Mendes, J. E. T. A enxertia do cafeeiro - III. Bol. da Super. dos Serv. do Café do Estado de São Paulo 23: 256 e 381-390. 1948. 